\title{
Challenges and Prospects of Developing in Asian Countries in the Non-Life Reinsurance Markets
}

\author{
by M. S. Wijenaike*
}

\section{Introduction}

The so-called Asian Reinsurance market is in fact a conglomeration of many markets each uniquely different. Markets, which vary greatly in size, degree of sophistication, structure, and stage of development. To this may be added the human factor of widely differing socio-cultural backgrounds that influence and impact on the conduct of insurance and reinsurance business in so many ways.

Asia has grown rapidly and today it is one of the fastest growing regions in the world; a growth which is expected to continue into the next century. The growth as between countries has not been uniform. Sub-regionally East-Asia has already grown very rapidly. China has one of the highest rates of growth in the world. Growth in South Asia has been less spectacular. However policy reforms and structural changes directed to encourage accelerated growth have had the desired effect with several countries being able to increase their growth rates.

International reinsurers, with the capital and technical resources available to them, have long dominated the Asian markets. Unlike international reinsurers, Asian reinsurers are small and comparatively few in number. They derive their sustenance primarily from their home markets. Hence their health and well being is conditioned and closely linked to that of the domestic markets. Thus this paper touches as much the primary markets and reinsurance. There is no homogenity in the Asian market as a whole. However if the market is subdivided into three categories - the smaller markets, larger markets and the markets that serve as reinsurance centres, some common characteristics may be discerned within each group. This paper does not deal with the well established markets of developed countries in the region notably Japan and Australia as their role in the Asian Reinsurance market would be akin to that of reinsurers from Europe and America. They are today more active than before and in the years to come they should play a very leading role in the Asian countries.

\footnotetext{
* Chief Executive/General Manager, Asian Reinsurance Corporation, Bangkok.
} 


\section{Historical background}

The growth and development of the insurance and reinsurance industry in the developing countries of Asia is comparatively recent. Insurance in most Asian countries was entirely in the hands of foreign companies until the turn of the second half of this century. The political and ensuing economic changes which followed World War II provided an impetus for the establishment of domestic insurance companies. Their formation and growth was nurtured by the wave of nationalism that swept through the region as Asian countries regained their independence. The domestic markets also received much encouragement from the efforts of the United Nations Conference on Trade and Development (UNCTAD) which advocated the establishment and strengthening of insurance and reinsurance institutions so that they could contribute to the development and growth of developing countries and reduce the outflow of foreign exchange by way of reinsurance or transfer of profits by foreign insurance companies.

Legal frameworks were introduced in many countries to promote domestic insurance companies either by limiting or eliminating foreign competition. Others went further by creating state monopolies and by the close of 1980 there were 15 such organizations.

At the risk of digressing, some comments on state monopolies are necessary as they were a common feature in Asia and have significantly influenced the insurance industry. Nationalization was once seen as a panacea for ills affecting the insurance markets of the newly developing countries. Today the thinking is different and the clamour is for privatization and market access. Let it however not be forgotten that in their time, these state monopolies did bring immense benefits to the countries concerned as they fulfilled the objectives for which they were created of generating funds for national development, conserving foreign exchange particularly by reducing the market dependence on reinsurance, and eliminating transfer of funds by way of profits of foreign insurers. Some of these institutions may have fallen short in service or in some other respect but the benefits far outweighed the shortcomings.

State monopolies enjoying, the widest possible spread and able to enforce rates unfettered by pressures of competition, were able to build up vast reserves and develop rapidly. Markets with this background today are more viable, technically competent, financially strong and better equipped to meet the challenges of tomorrow.

\section{Reinsurance}

The history of the indigenous Asian reinsurance industry is of even more recent origin and much less impressive. This is understandable as they had no raison d'être until the domestic insurance industry established itself.

A few Asian professional reinsurers did establish themselves in the 1950's notably in India, Indonesia and Philippines but primarily to cater to the needs of their local market. During the last three decades the numbers increased as several more reinsurers, both national and private, were established to meet the needs of a growing insurance market in which indigenous insurers were begining to play a dominant role. However, only a few of these reinsurers operated on a truly international scale. In addition to these several state insurance companies such as those in Bangladesh, India, Pakistan, and Sri Lanka took upon themselves the role of Reinsurer especially for their own markets. 
In Thailand the insurance companies joined together to create a National Reinsurer, the Thai Reinsurance Company (1978) and Philippines did likewise to create the National Reinsurance Corporation (1978). Indonesia, Korea, Malaysia and Singapore also have national reinsurers who are supported by the market. These reinsurers play a very important role in their respective markets.

Running parallel to these developments were the efforts of U.N.C.T.A.D./E.S.C.A.P. and other intergovernmental organizations to promote regional, inter-regional and subregional cooperation. In Asia these efforts saw the creation of the Asian Reinsurance Corporation (1979), Asean Reinsurance Pool (1981) and the Asean Reinsurance Corporation (1988).

The Asian insurance market outside Japan is comparatively small and constitutes only around $3 \%$. of the world's non-life premium income. Its importance however lies in its future potential. The gross premium income of some of the smaller Asian countries is less than that of a medium size insurer in U.K. or U.S.A. Nevertheless they evoke much interest of large international reinsurers and brokers.

To present a clearer picture of the so-called Asian Insurance and Reinsurance market a brief overview of a selected cross-section of its components is given below.

\section{The smaller markets - Primarily buyers of reinsurance}

\subsection{Afghanistan}

Afghanistan is a small market with an unbalanced portfolio, but yet consistently profitable results. Insurance was in the hands of foreign insurers upto 1964 when the government established a joint-venture company with Guardian Assurance. In 1972 Insurance was nationalized and the Afghan National Insurance Company established. The gross market premium in 1991 was US $\$ 4.95$ Mil. of which $92 \%$ was in respect of Aviation. Laws have been amended now to permit establishment of local companies but none have yet been established. The local market is ill equiped to compete effectively with foreign competition.

There is no professional reinsurance company in Afghanistan.

\subsection{Bangladesh}

Insurance in Bangladesh was in the hands of 42 domestic and 8 foreign companies prior to nationalization of insurance in 1972, when the Sadharan Bima Corporation (SBC) was created to transact all Non-Life business. In 1985 the market was re-opened and today 16 Non-Life companies operate in competition with SBC.

In the field of reinsurance, these companies are obliged to cede $50 \%$ of the reinsurable Non-Life business to SBC and are free to place the balance outside. In practice the companies have been placing almost all their reinsurance with SBC. In this context the country retentions have in fact increased after privatization. The reinsurance results in Bangladesh had been positive over the years until 1991, when Cyclone losses left a very deep impact. Exposure to natural hazards and difficulty to obtain reinsurance protection for it at reasonable cost is a matter of concern. At present, inward reinsurance accepted by Bangladesh is very limited. As the domestic companies grow, there are prospects that reciprocal trading with particularly neighbouring countries may reduce the net outgo on reinsurance though not to any appreciable extent. Inter-company reinsurance is not popular although 
co-insurance is common. In the event of liberalization, the market is confident that it could effectively face foreign competition.

The gross market premium in 1991 was Taka 2,307.5 mil. (approx. US\$58 Mil.). The largest single class of business is Marine Cargo.

\subsection{Bhutan}

Bhutan has only one insurance company which is a joint venture with the government holding $61 \%$ and the public $39 \%$. The insurance and reinsurance business results in the country have been very positive over the years but the market with a gross premium in 1992 of $\mathrm{Nu} .40,335,000$ (US $\$ 1,301,129$ ) is small.

The country is particularly dependent on the regional markets for its reinsurance. The quality of their own business enables them to engage in reciprocal trading but yet there is a net outflow on reinsurance, a situation which is likely to continue. If the market is to be opened, the local company may not be able to effectively cope with foreign competition.

\subsection{Brunei}

The Brunei insurance industry though the smallest among the ASEAN countries is one which is steadily growing with country's economic development.

In 1993 there were, including the two Takaful companies, 20 insurers operating in the country: 4 domestic, 4 subsidiaries of foreign insurers and 6 foreign insurers represented by local underwriting agencies. The gross market premium was B $\$ 75,159,000$ (US\$ 47.3 mil.). Motor insurance accounts for more than half of the market premium.

A Brunei Reinsurance Corporation was incorporated in 1991 but has not yet commenced to operate. The local capacity is limited and dependence for reinsurance support is heavy and likely to continue. The local retention ratio in 1993 was $65.2 \%$.

\subsection{Myanmar}

There is only one insurer in Myanmar, the state owned Myanmar Insurance. Reinsurance is placed in London through brokers. For Fire and Marine they rely on Non-proportional reinsurance. Engineering Aviation and Oil and Gas are on a quota share basis. The dependence on the international reinsurance market is likely to continue. The premium growth has not been steady in the past except in Third party Motor insurance. The annual gross non-life premium income in 1992 amounted to approx. Kyat 416 mil. (US\$ 66.0) of which automobile accounts for almost $50 \%$.

\subsection{Nepal}

Nepal is a small and profitable market which follows the Indian tariff. In the $1950 \mathrm{~s}$ there were only two local and two foreign companies in operation. Today, with recent changes in the law relating to the establishment of new insurance companies, the number of domestic companies have risen to seven. The largest insurer is Rastriya Beema Sansthan, established in 1968 with the State retaining a controlling interest. The estimated gross nonlife market premium income for 1994 is NRS. 500,000 Mil. (US\$10.2 Mil.). Nepal relies on both the regional and European markets for its reinsurance. 


\subsection{Sri Lanka}

Insurance in the post war years till 1962 was largely in hands of foreign insurers although domestic companies also operated. In 1962 insurance was nationalized and the Insurance Corporation of Sri Lanka (ICSL) was made sole insurer. In 1980 another state insurer, the National Insurance Corporation (NIC), was established to provide competition to ICSL and thereby improve service. In 1988, the Government following a free market policy permitted private insurance companies to operate, and in that year three private companies were established. Two of these companies have technical assistance from foreign insurers. Collectively they have a fair share of the market, but ICSL continues to have the major share.

There is no professional reinsurer in Sri Lanka but the private insurers have to cede to the NIC $15 \%$ of their Fire and Marine business. With this, and the very high retentive capacity of ICSL and the steeply increasing retentive capacity of the private companies, the market retention is quite high. As the results of the reinsurance business over the past decade have been extremely profitable, the market has cnjoyed very favourable terms from the international markets for the proportional covers. In the event of liberalization some of the local insurers could effectively compete with foreign ones.

The gross market premium in 1992 was Rs. 2,862 mil. (US\$58.4 mil.). This figure does not include Aviation. Neither the State Corporations nor the private companies accept inwards reinsurance business.

\subsection{Vietnam}

The domestic insurance market was from 1964 entirely under the control of the Vietnam Insurance Company (Baoviet). In January 1994 a new state decree declared the opening of the country's business insurance sector to overseas insurers. The gross non-life premium income in 1992 was estimated at Dong 400 mil. (US\$ 36.5). According to press reports, the Finance Ministry has announced the establishment of Vietnam's first Reinsurer, the State owned Vietnam Reinsurance Co. (VINARE) capitalised at US\$ 4 mil. Insurers operating in Vietnam will be required to make a $15 \%$ cession to this company.

\subsection{Summary}

The smaller markets, apart from size, have other common characteristics. Almost all of them have been profitable markets over the years both for direct underwriting companies and reinsurers. All but one have a government controlled organization playing a major, if not sole role in the market. The markets are all heavily dependent on the international markets for Aviation and other specialized and high risk value coverages. The outgo on reinsurance is hardly offset by the acceptance of inward reinsurance though a few markets do engage in some reciprocal trading or acceptance of selected business. Such acceptance would not exceed $10-20 \%$ of the outgo. The markets being small could bring to bear very little influence on international markets but those with consistently good results and little exposure to natural hazards do enjoy very favourable terms on their proportional business.

The leading professional Reinsurers as well as international Brokers are very much involved in all but one of these territories and even in the exception they handle Aviation. The total non-life gross premium income of the markets, referred to above, amount to less than US\$300 mil. which is approximately a fifth of the premium generated in a single territory like Thailand or India or little over $3 \%$ of the premium income of the world's largest reinsurer. 


\section{The larger markets}

\subsection{China}

The People's Insurance Company of China (PICC) created in 1949 had a monopoly of insurance till 1988. In 1988 the People's Bank of China which regulates the insurance market authorized the establishment of two new insurance companies: The China Ping An Insurance Co. and China Pacific Ins. Co. In 1993 the AIG was licenced to underwrite both foreign property and individual life policies, followed by Tokyo Marine and Fire. A Law to provide a framework for companies to operate in China's expanded and diversifying insurance market is under consideration. Liberalization presents no problems as local companies could compete effectively. With the size of the country and the geographical possible spread, China's need for reinsurance is greatly minimised. However for Aviation Marine Hull and Cargo, CAR and large risks particularly, joint ventures, considerable reliance is placed in reinsurance. With the strong growth in foreign investments the premium generated from this source was estimated at US\$340 mil. in 1991.

The gross market premium in 1993 was $23,279.2$ mil. Yuan (US\$ 2,732.9 mil.). This figure does not include business underwritten by the two foreign insurers whose market share is not significant. Reinsurance premium ceded was $1,719.7$ mil. Yuan which was only slightly more that inward reinsurance premium received of 1,679.88 mil. Yuan. The growth in the insurance sector as reflected in the growth of the PICC is spectacular, varying from $20 \%$ to $60 \%$ between $1980-1992$.

China has no National Reinsurer but PICC performs this function. It receives a $30 \%$ compulsory cession from the other local companies.

\subsection{India}

In India, Insurance has a long history since the 19th Century when foreign companies first operated. India, especially after World War II, saw the growth and development of some very strong local insurance companies whose operations extended beyond the shores of India. In 1956 life insurance was nationalized and in 1972 there was full scale nationalization of the industry. The General Insurance Corporation (GIC) was established as a government company for purposes of superintending, controlling and transacting general insurance business. The erstwhile 107 insurers were integrated to form 4 subsidiary companies which operate on an all India basis in competition with one another within the framework of uniform industry objectives. As for the future, changes are likely. A committee on the reform of the industry headed by Mr. R.N. Malhotra has submitted a report that underscores the need for progressive deregulation of the insurance sector to create a more competitive and financially strong insurance industry. Market programmes and obligations to make cessions to GIC ensure optimum retentions within the country. The retentive capacity of the Indian market is thus very high and estimated to be over $80 \%$. The companies are strong and could withstand competition in the event of liberalization of the industry. The Indian companies actively engage in the acceptance of reinsurance from abroad so unlike most countries in the region the net outgo on reinsurance is greatly reduced. The gross market non-life premium in 1992/1993 amounted to Rs. $47,320,000,000$ (US\$ 1,508.4 mil.). 


\subsection{Islamic Republic of Iran}

The first foreign insurance company in Iran was established in 1930 and the first local in 1935. Bimeh Markazi Iran was established in 1971 as Supervisor and Regulator. All Insurance companies have to cede $25 \%$ of non-life business to Bimeh Markazi. It also acts as the National Reinsurer and operates internationally. In 1979 insurance was nationalized and three nationalized companies were permitted to operate. The gross market premium in 1992 was Riyal 206,000 mil. (US $\$ 2,492.9$ mil. at then official rate of exchange). The largest classes of business are Marine Cargo and Motor. In the event of liberalization local companies could effectively compete with foreign insurers.

\subsection{Republic of Korea}

The first local insurance company was established in 1921 and the first foreign in 1925. With the introduction of the insurance business Law in 1962 and steps taken by the government to foster the industry, the industry began to develop. In the 1970's the industry grew rapidly with the country's overall economic development. The 1980's saw moves towards liberalization and internationalization, and market access was permitted to foreigners after 30 years of closed market structure.

Today the non-life market consists of 13 domestic companies, 3 foreign companies and one reinsurer. The gross market premium 1993 was Won. 6,780,000 mil. (US\$ 8,475 mil.) The insurance industry has shown a growth rate of approximately $21 \%$ since 1990 . All insurers are obliged to cede a portion of their business to Korean Reinsurance Company (KRIC). Also when non-life insurers place their reinsurance contracts they are required to preferentially cede reinsurance contracts to other domestic insurers before placement abroad. KRIC, the only reinsurer permitted to establish in Korea, plays a very active role both in the domestic market as well as in the international market. Among the Developing countries of Asia/Pacific, it is the largest reinsurance company and among the first 40 world reinsurers. With maximization of retentions within and an inflow of foreign business, Korea has been able to minimise the net outflow on reinsurance. The market is confident it could face foreign competition.

\subsection{Indonesia}

Indonesia is an important market in the region with great potential due to its relative political stability and vast population. In the non-life sector it has 90 insurance companies of which two are State and four Reinsurers - (two State and two private). The gross premium income in 1993 was Rp. 1,989.9 Billion (US\$ 949 mil.), an increase of $13.4 \%$ over the previous year. Fire business continues to be the single largest line of business. The gross premium received by reinsurance companies in 1993 was Rs. 371.2 Billion (US $\$ 177$ mil.), an increase of $39.38 \%$ over the previous year.

Since the deregulation of the insurance industry in 1985 and the introduction of Law no. 2 of 1992 concerning insurance business, joint ventures can be established in Indonesia and at the close of 1993 there were 14 non-life Joint-venture companies. The presence of a large number of companies in the non-life sector has resulted in severe competition. 
The Indonesian market has met problems in arranging reinsurance protection due to poor results. Stiff reinsurance terms, restrictions on perils covered and exclusion of certain classes of business have had a severe impact on the underwriting capacity of the insurance companies.

\subsection{Malaysia}

The Malaysian Insurance non-life market as at the close of 1993 comprised of 41 General Insurers 13 Composite Insurers and 2 General Reinsurers. Two foreign reinsurers have since been permitted to operate. The general insurance industry continues to grow and in 1992 the written premium was Rm. 2.89 Billion (US\$1137.8 mil.) which represented an increase of $20.6 \%$ over the figure of the previous year. In $1991 \mathrm{Rm} .576 .7$ million being $24 \%$ of the written premium was remitted by way of reinsurance premium to foreign reinsurers. The reinsurance premium accepted from overseas in 1991 amounted to $\mathrm{Rm}$. 55.6 million.

In order to increase local retentions, a scheme for the insurance of large and specialized risks was introduced in 1994. The scheme is managed by the Malaysian National Reinsurance Bhd. The promotion of co-insurance in the market is also under consideration in order to augment reinsurance capacity within the country.

The Malaysian Re International is active both locally and internationally particularly in the regional markets.

In the meantine the Labuan International Offshore Financial Centre is being developed and already 5 insurance companies are located there. The intention is to develop this facility into an insurance centre.

\subsection{Pakistan}

In 1947 there were five domestic companies and seventy-seven foreign companies. In 1952 the Pakistan Insurance Corporation was created to promote local companies and to meet the growing needs of the market. A national co-insurance scheme was also established in 1955 to help smaller companies to grow. This was later converted into the National Insurance Fund and finally into the National Insurance Corporation in 1976.

The market in Pakistan is presently mixed with domestic companies, foreign companies as well as State owned insurers operate therein. There are 55 private insurers of which 10 have foreign interests. The State owned National Insurance Corporation covers property owned by the public sector and has a premium income of over Pak. Rs. 1,350 mil.

The State owned Pakistan Insurance Corporation (PIC) established in 1952 functions as a National Reinsurer. The P.I.C. initially received a $30 \%$ cession but this was reduced to $20 \%$ in 1993. The P.I.C. also provides reinsurance upto $25 \%$ of the Surplus before reinsurance can be placed abroad. Co-insurance is common in the market and this together with the operation of the P.I.C. have helped to keep overall retentions at a high level.

The five largest companies in the market together with NIC account for more than $70 \%$ of the market premium with largest company alone writing over $23 \%$ of the total non-life premium. In 1993 the gross direct non-life premium of the market amounted Rs. 5.46 Billion (US\$181.9 mil.). 
Motor and workmen compensation accounted for $33 \%$ and Fire $30 \%$ of this premium. In 1991 premium paid on reinsurance ceded outside Pakistan amounted to Rs. 670.3 mil. as against Rs. 72.0 mil. received on inward reinsurance.

\subsection{Republic of Philippines}

Philippines has a long insurance history with the first foreign company being established in 1829 and the first domestic company in 1906. The first local reinsurer was established in 1956. As at the end of 1992 there were 98 non-life insurance companies in operation of which 9 were foreign. There were also four reinsurers in the market of which one was foreign. The National Reinsurer is the National Reinsurance Corporation (NRCP). Insurers are obliged to cede $10 \%$ of all their outward foreign insurance to NRCP.

Philippines, due to its exposure to natural hazards and the worldwide reduction in reinsurance capacity, has had to face many problems in securing reinsurance protection. Effective from January 1994 major international insurers imposed new conditions on proportional treaties. Some of these provisions restricted the risk of accumulation to reinsurers particularly on natural perils, imposed a flat two percent deductible on all losses caused by earthquake typhoons and floods and increased substantially the premium rates against natural disasters. Business interruption following such disasters are no longer covered including losses caused by volcanic eruptions and all perils following this type of catastrophe.

The Non-life premium income in 1992 was Peso 10.53 Billion (US\$ 400.3 mil.) whilst the total net premium retained amounted to Peso 6.99 Billion, representing a retention rate of $66.38 \%$.

In the past two years the gross premium has been growing rapidly at around $20 \%$ each year, part of which reflects rate adjustments. This growth is likely to be sustained if not exceeded with the current economic developments in Philippines.

\subsection{Taipei}

As at 1993 there were 15 local and 7 foreign non-life insurers and one reinsurer. In 1992 total premium reached NT\$52,993 Million representing a $19.32 \%$ increase over 1991 . Automobile insurance was the largest line with $59.68 \%$ followed by Fire $(20.19 \%)$ Marine $(10.36 \%)$ and Casualty $(9.77 \%)$.

The reinsurance placed abroad was comparatively quite high at NT\$22,790 million or $43 \%$ of the written premium in 1992.

In 1994 provisions were made for entry of foreign insurance companies and the insurance market was made completely open. This was a move to prepare for entry into GATT and to promote liberalization and internationalization in the insurance industry.

\subsection{Thailand}

The Thai non-life insurance industry consists of 56 non-life companies, 5 composite 6 health and 2 reinsurance companies. The Thai Reinsurance Company is a national one owned by the insurance companies. The Asian Reinsurance Corporation, an intergovernmental organization established by the $U N$ is the other reinsurer based in Thailand. The direct written premium (non-life) of the Thai market for 1992 amounted Baht 25,240 mil. (US\$ 1,001.5 mil.). With the introduction of compulsory third party motor insurance, premium income increased further rising steeply to US\$1,447 mil. in 1993. 
Thailand is a tariff market which for almost a decade except for one year has shown consistently good fire results both for direct underwriting companies and reinsurers. The Thai Marine portfolio is comparatively small. Motor is the major line of business.

The retentive capacity of the Thai market is high, estimated at around $75 \%$. The retentions of the market are maximised by arrangements made by the Thai Reinsurance Company which also receives an obligatory cession and voluntary cessions from the market.

The larger markets of Asia with their bigger premium base and spread are stronger and less dependent than the smaller markets on foreign reinsurance except for specialized covers and catastrophy protection. The presence in these markets of a powerful National Insurers and Reinsurers as the case maybe provides them a means of promoting a measure of market discipline and control, and in the open markets of making arrangements to maximise national retention. These markets being relatively large, in times of adverse results, they are less at the mercy of international reinsurers than the smaller markets, which reinsurers could afford to lose.

The big insurers are already well established. Many are a part of large financial or industrial groups and benefit by in-house business. Most smaller insurers cater to a selected clientele with whom they have some community of interest. The profitable markets in this group that have not yet opened their markets are under pressure to do so but foreign insurers, if permitted to operate, will take time to penetrate the markets.

Common to most of these markets is also the pressure by the international reinsurers for more realistic rating especially for natural hazards and greater control on claims.

\section{Emerging reinsurance centres in Asia}

Singapore and Hongkong stand out as the leading reinsurance centres in Asia; Australia has also shown interest in developing into one whilst Malaysia has provided incentives to make Labuan an Insurance and Reinsurance Centre.

\subsection{Singapore}

Political stability, a strategic location, an excellent infrastructure and a well developed financial sector have all contributed to make Singapore an attractive Centre.

Singapore as a reinsurance centre has flourished with many international reinsurance companies setting up operation. Offshore business in Singapore has grown in importance over the past decade and together with the contribution of captive insurers domiciled in Singapore the offshore busincss accounts to little less than half the total general business. The non-life premium income in 1993 was $\$ \$ 2,369.3$ mil. (US\$ 1,490.1 mil.) of which offshore premium was $48.1 \%$ and domestic $51.9 \%$. The retention ratio for domestic business was $84.2 \%$.

The Singapore insurance market, as a regional centre, is highly international in character with almost $75 \%$ of those operating being foreign. As at 1st January 1993 there were 44 non-life, 44 direct insurers, 27 Professional reinsurers and 46 Captive insurers; in addition there were 6 composite direct insurers and 5 reinsurers. There are at present around 16 Brokers transacting reinsurance business on an international scale. The Singapore Reinsurance Corporation is the national reinsurer and was established in 1973 with equity participation 
of all direct insurers in the market. It receives cessions from direct insurers to the extent $5 \%$ in fire and $2.5 \%$ in other classes subject to varying maximum amounts. Singapore is also the home of Asean Reinsurance Corporation.

\subsection{Yongkong}

The Hongkong economy has shown steady growth. With its thriving economy the insurance industry has also grown.

As at the end of 1993 the total number of non-life insurers was 170 and that of composite insurers 19. More than half the non-life insurers were incorporated in Hongkong.

The gross non-life written premium income for direct business in 1992 was HK\$10.988 mil. (US\$ $1,423.16$ mil.) a growth of $19 \%$ over the preceding year.

The communication facilities in Hongkong are excellent. Its geographical location places it in an advantageous position in obtaining business from neighbouring countries of high economic growth. Probably its greatest attraction in the present context is its proximity and access to China where a vast insurance market is emerging. Hongkong does not discriminate between insurers incorporated locally and those incorporated overseas. However rising costs in Hongkong and difficulties in retaining staff are problems that reinsurers will have to face.

The reinsurance centres in Asia Hongkong and Singapore have a bright future and will grow with the region. The major players in international reinsurance market are well represented and there is an increasing tendency among markets in the region to utilise these two regional centres particularly for facultative reinsurance.

\section{Some matters of current concern to Asian markets}

\subsection{Pricing in international markets}

A very longstanding and contentious issue among Third World Insurers has been the excessive price they have been subjected to by international markets for non-proportional covers, particularly catastrophe covers and for reinsurance of specialized risks Aviation etc., terms, felt by many not warranted by their own experience.

Asian Insurers and Reinsurers, a very few exceptions apart, confine their operations to Asia. Most do not venture beyond their own boundaries. Yet today they are affected by every earthquake that jolts the American continent or hurricane that sweeps across Europe as international markets recoup losses based largely on their global experience. It is a fact that increases in international reinsurers' own protections costs get filtered down to (Asian) reinsureds who have had to pay more for their protection despite clean records and no increase in exposure.

Almost all internationally operating reinsurers including Lloyds incurred heavy loss between 1990 and 1993. Many reinsurers were forced out of the market resulting in a drastic reduction in retrocession and reinsurance capacity. The insured losses due to catastrophes were heavy such as Hurricane Andrew (1992) - US\$16.500 mil. Winter Gales - Europe US\$ 10,000 mil. Floods - China (1991) US\$ 410 mil. Hugo (1989) US\$4,500 mil. Thyphoon Mirelle Japan US\$ 5,200 mil. Earthquake San Francisco (1989) US\$900 mil. Earthquake 
Los Angeles 1994 over US $\$ 10,000$ mil. The losses in the developing countries of Asia were few and very small in comparison. The loss in China was the largest but did not fall much on the international market.

The large losses in Asia outside Japan caused by natural perils were mainly confined to the Cyclone loss in Bangladesh, the earthquake in Bagio Philippines and Storm loss Pusan Korea; all of which were below US\$100 mil. each.

An impression has been created among Asian insurers and reinsurers that when rates are revised on global experience, the burden falls less harshly on the larger markets in which international reinsurers have invested much and wish to maint ain their presence than on the smaller markets of Asia which are heavily dependent on them and they could afford to take liberties with.

The consensus among Asian insurers and reinsurers is that the international reinsurance market operates in such a manner that they get the worst of all possible worlds - the price they have to pay for their protection being based on their experience and exposures or that of the global experience which ever is more unfavourable.

The following is an extract from a United Nations Publications on Insurance in Developing countries 1984/85.

"Developing countries feel that they are paying today an excessive price for all the reinsurance markets troubles in recent years. A period of relaxed market practices and low reinsurance premia in the international reinsurance arena have given way to a period of hardened reinsurance conditions underwriting limitations and increased prices. But developing countries claim that since they had not been the main beneficiaries of the former conditions they should not be the victims and pay for the latter." The same source quotes the case of the aviation fleets of Africa and Asia which have been subject to premium increases of 60 and $40 \%$ respectively increases which do not compare with increases of fleets for developed areas which had less favourable loss ratios.

Today, a decade later, similar sentiments are still strongly expressed by Third World Insurers and Reinsurers. This was evidenced at the recently concluded EAIC Meeting in Seoul where Asian insurers complained that they were being made to pay for the misfortunes of others and called for Asia to be rated on Asian experience rather than global. A call for the creation of an Asian Mega Reinsurer, and for Japan to take a lead in the region to create a regional pool to provide the markets therein with protection for catastrophe losses, was indicative of the mood of Asian insurers. However in the case of facultative and proportional business with good results Asia enjoys favourable terms except in territories that are highly exposed. Asia's dependence on the international markets for facultative reinsurance, as well as for rating and terms for certain types of risks is fairly substantial. This business is mainly placed through brokers particularly those in U.K., Hongkong, Singapore or those represented in the countries concerned. U.K. and European reinsurers are substantially involved in writing this business.

In the territories where proportional business is yet profitable the terms are so loaded against the reinsurer that it leaves only a very limited margin if the business is profitable, but with unlimited loss potential if business proves otherwise. While high commission rates coupled with profit commission limit the reinsurers' profit margin, the premium reserves 
provision makes the cash flow often negative for reinsurers. With at best only marginal profits possible, reinsurers face a daunting task of building reserves to cover the large single or catastrophe losses to which they are exposed.

\subsection{Liberalization}

The trade liberalization of goods and services which includes insurance being now inevitable, it has caused much concern among Asian insurers. The prospect of facing the unequal competition from highly capitalized and technically more proficient insurers to many is disheartening. The basic premise of the Uruguay Round negotiations was that the opening of barriers would provide new opportunities for trade expansion to developing countries and enhance their prospects for economic growth.

In the field of insurance this theory when translated into practice would result in especially the smaller Asian insurers being either eliminated or greatly curtailed in their own market without any corresponding advantage elsewhere. It would be ludicrous to believe that, a very few exceptions apart, if any, Asian insurers could establish themselves in the Developed countries. The high minimum capital and other stringent requirements that need to be complied with for establishment, coupled with the prospect of competition with highly capitalized and well established domestic companies would deter Asian insurers from looking for markets in the developed countries.

The capital of many Asian insurers is insufficient to succeed in an open market environment but with reinsurance support they could make ground. A survey was conducted in ten markets to ascertain the views of the local insurers how effectively they could, in the event liberalization, compete with foreign companies.

In five of the markets the domestic companies expressed confidence in their ability to meet foreign competition. In three the assessment was that the larger companies could compete but not the smaller. Two markets both small were of the view they could not successfully withstand foreign competition. In the countries, where the local market was confident in meeting foreign competition, insurance was in the hands of financially strong monopoly insurers or were erstwhile monopolies or markets where insurers had close connections with their insureds. Whilst an open insurance market will benefit the consumer and make it more sophisticated, to the local insurer it presents problems and new challenges without any corresponding advantages or benefits. For many developing countries it would imply the dismantling of restrictions once placed on both cross-border and establishment trade whilst the reasons for initially setting up these restrictions still remain valid.

The implications as far as reinsurance is concerned are however somewhat different. International trade in reinsurance has been relatively free of interventionist measures and hence there will not be much change. However with increased competition in the primary markets and consequent reductions in rates and standards, business will become less attractive to reinsurers.

It must also be emphasised that the business base of an Asian Reinsurer lies mainly in his own country. Thus, when with market access foreign insurers capture a share of a local market, then the local reinsurer is likely to suffer a corresponding loss of reinsurance business. Also if the larger insurance companies establish in a market, with their greater retentive capacity recourse to reinsurance, to international and other reinsurers operating in the market will be reduced. 


\subsection{Protection agairtst natural hazards}

Losses arising out of natural hazards have taken a very heavy toll from reinsurers in the recent past. Asian markets, particularly those more exposed, find it increasingly difficult to secure reinsurance protection against catastrophe losses arising out of natural hazards at an affordable price. Asian insurers and reinsurers feel that they are already paying an excessive price. It is unlikely that the international reinsurance community thinking on the subject can be radically altered. Asia needs to look more to itself to find ways and means to underwrite these risks.

It needs to be appreciated that weather patterns have changed drastically in the past decade increasing both the frequency and scope of natural catastrophes. At the same time in Asia with its rapid development there has been a trend towards ever increasing concentration of risks in development zones and other geographically confined areas. To this extent it can well be said that prices that reflect the past are no longer valid but prices which anticipate likely future loss development could also be questioned.

The support of international markets for catastrophe protection will always be necessary but by taking appropriate measures at all levels not only could dependence on international markets be lessened but also better terms obtained. Greater self-reliance could be achieved if:

i) Rates for protection against natural perils are made more realistic and a rating structure devised that would encourage insureds to undertake loss minimization measures;

ii) Deductibles are imposed so that the insured also participates in loss;

iii) Measures are taken to control accumulation and also provide a realistic picture of exposures so that reinsurers are able to properly assess their commitments;

iv) As the rate for catastrophe perils is based on the assumption that a loss is expected to occur once in an assumed number of years it is essential that each year's surplus from operations be set aside as reserves for the future. For the same reason governments should not tax any surplus as they really do not constitute profit;

v) Since reinsurance capacity and rates are influenced by global experience and may not reflect Asia's experience, Asian governments should seriously consider taking steps to create and support a pool for catastrophe risks, either on a national or on a regional basis. The latter may be difficult. The pool itself could seek protection from the international reinsurance market and as funds build up dependence on the international reinsurance market could be reduced. Today many reinsurers are reluctant to provide natural perils coverage or are prepared to do so only to a limited extent and at a price.

Loss limitation clauses are now even being included in some proportional treaties in certain markets. The trend is quite clear and each market should take steps as appropriate, otherwise, they may soon be left with a shortfall of cover they may not be able to cope with.

\subsection{Supervision and control}

The future direction of the Asian insurance and reinsurance markets is very much in the hands of the Regulators. The need for market discipline cannot be over-emphasized. Market forces alone cannot bring about such discipline. Insurers and reinsurers do take 
steps to improve markets and bring greater stability but concerted action is extremely difficult. There will always be someone prepared to undermine the process merely to enter a market or if already in it to enhance its position.

In many markets the authorities are content so long as insureds are able to enjoy favourable rates, although the rates may not be commensurate with the risk run by insurers - a case in point is the rating of most of the Industrial All Risks policies. Solvency margins are based on premium and if the latter is inadequate the former will likewise be insufficient. If Asian markets are to develop, regulatory authorities need to ensure that tariffs, if not, some minimum premium rates commensurate with risk, are observed; and also that measures are taken to promote increased capitalization, higher market retention and more accurate compilation of statistics relating to catastrophe exposures etc. In many Asian countries, and in particular Asean countries, Regulatory authorities are well equiped and staffed to perform their function. In some countries however the authorities have not been provided with the required facilities to be effective.

\subsection{Training and education in Asia}

There is an urgent need in many Asian countries to train and educate staff at all levels and this applies both to insurance and reinsurance.

This will ensure that basic business will be well written and the insuring public well served. Improvement in quality will result in improvement of reinsurance terms and conditions. Development of reinsurance expertise will ensure that reinsurance programmes are properly designed to meet ceding company requirements and protection costs reduced to minimum. It will also enable those companies accepting inward reinsurance business to accept business of good quality.

The training of personnel is also necessary to reduce the dependence of companies in the region on international Brokers and Reinsurers for technical assistance. Such assistance is naturally not rendered purely through altruistic motives, and those rendering such services expect to be rewarded with profit through business they obtain from the companies concerned.

The need therefore to strengthen all institutions in the region that provide technological services and promote expertise in fields of insurance and reinsurance cannot be overstressed. The United Nations have for over three decades taken an active interest in this field. When they created the Asian Reinsurance Corporation (Asian Re) in 1979 the development of expertise in insurance and reinsurance and provision of technical assistance to national insurance markets were two of the four main objectives. Asian Re has done much in the furtherance of these objectives.

\subsection{The need for a mega Asian reinsurer}

In the emerging countries of Asia a consensus has understandably emerged that the creation of an Asian Mega Reinsurer would serve to largely meet or mitigate some of the problems currently besetting their markets, particularly the high cost of reinsurance and dependence on international markets.

Regionally the required capital and expertise is available but it needs to be suitably harnessed. This is no easy task. 
The concept of such an Asian Reinsurer is not new. It was first conceived in 1971 by the United Nations and gave birth to the Asian Reinsurance Corporation (Asian Re) in 1979. Its operations and performance should provide a source of inspiration, now that the idea has been revived. Asian Re has successfully operated in the region for 15 years with much acceptance. It provides an excellent example of the benefits of regional Co-operation and how countries of vastly differing size, divergent cultural, political and economic backgrounds can harmoniously work together pooling resources, for mutual benefit. What is more important is that the participating countries have got to know each other and their markets and close bilateral ties have developed between these countries, many of which did not have connections with each other till their common association with Asian Re.

Asian $\mathrm{Re}$ when it was created was envisaged to encompass most if not all the developing countries of Asia and Pacific but largely due to the inability of many countries to raise the required capital, membership of Asian Re and hence its capital was limited. Asian $\mathrm{Re}$ was thus not able to play an as important role as was expected. Presently Afghanistan, Bangladesh, Bhutan, China, India, Iran, Korea, Philippines, Sri Lanka and Thailand geographically covering the greater part of Asia, are members of Asian Re. Had it received the expected wider support Asia today would not have cause for past regrets on the future fears.

One more powerful Asian Reinsurers well supported and accepted by the national markets will not only be in Asia's interest but also in the wider interests of the international market as it could serve to mitigate the feelings Asian Insurers have that they are invariably victims of circumstances they are not reponsible for. Asian Reinsurers cannot replace the international market but can play an important complementary role. They could work more closely and with greater understanding with the local markets that created them and serve as a very useful bridge between the Asian primary markets and the international markets.

\section{Looking ahead}

The rapid economic growth in Asia has not been matched by a similar growth in the insurance industry. The ready availability of reinsurance support as international reinsurers badly smitten elsewhere, sought to carve niches in Asia, and obviated the necessity for local companies to increase their capital base or to develop skills to write the larger and more complex risks that came into the market. The lure of writing business for the certain gain of commission rather than uncertain profit made most insurers quite content with writing business with technical assistance and backing of their reinsurers. Long-term benefits have and continue to be sacrified for short term gains. Most domestic and regional reinsurers are still not fully equipped by way of capacity and technical know how to provide the support required by local insurers so that greater beneficiaries in insurance of the economic growth in Asia have been foreign insurers and reinsurers. Today, given the other available opportunities in most Asian countries, attraction of capital for insurance and particularly reinsurance is difficult. However attempts are being made in certain territories by the concerned authorities to increase minimum capital requirements. Hopefully this should lead to the strengthening of the capital base of insurers through influx of new capital if not through mergers. The latter is more desirable as it would also ensure that limited available expertise is better utilised and competition reduced. Today in the Asian market there are far too many insurers who are merely fronting business and are no more than intermediaries of foreign reinsurers. 
Asian Reinsurers will also need to increase their capital to meet the growing needs where they will have to write larger net lines. This does not imply that the small Asian reinsurer will have no stake. In Asia relationships built over the years have a certain sanctity. Personal relations count. Asian reinsurers have been small enough to know their clients intimately and big enough to serve a part of their needs. Their physical presence in the markets are an added advantage. Those reinsurers who have served their clients well could expect to remain and grow with them. It is a part of Asian culture.

Whilst many complain that there is an excessive flow of reinsurance to the international markets, in many Asian countries the local capacity is not fully utilised before recourse to reinsurance abroad. In some countries such as Philippines, and Pakistan regulations require that the local market is fully exhausted before recourse to reinsurance abroad but in the changing environment such restrictive policies may not be acceptable. Market arrangements designed to maximise domestic retentions such as the schemes in India, Thailand and Korea have also proved very successful. There is however a tendency in many open markets to place facultative reinsurance abroad to prevent competitors having access to information on clients and risks.

The very substantial dependence of Asian markets on the international markets for catastrophe protection and for other non-proportional covers is bound to continue into the forseeable future. This also applies to Aviation, Marine, Hull and to other high value specialized risks in respect of which only the international markets have both the capacity, spread and expertise to underwrite.

The current trends in many open Asian insurance markets leaves room for much concern of their future stability and profitability. In these markets intense competition has made it difficult to maintain the right price or impose appropriate conditions especially for the large risks. Circumvention of tariffs, rebates and other subterfuges to provide insurance cheap characterize such markets.

"Industrial All Risks" policies perhaps best exemplifies how business is written in such territories, where a wide range of coverage is offered usually at a rate less than the basic fire rate. The coverage is sometimes so wide and indefinite that some day insurers and reinsurers could be faced with large and unexpected losses, more so as Court interpretations are much in favour of insureds. The retention of the company writing such business is comparatively small and the major part of the risk is reinsured at favourable commission terms. The net rate received by reinsurers is totally inadequate, yet, there are reinsurers particularly newcomers to the Asian market prepared to write it.

Without the willing support of reinsurers, insurance companies would not in the first place be able to write business at rates and terms they now write. However competition among reinsurers enables Asian insurance companies to obtain favourable terms for facultative and proportional business. In this they have been greatly assisted by those Brokers who act only with their market share in mind. They have been largely responsible for undercutting of rates by luring innocent capacity to provide reinsurance support at uneconomic terms. Such actions have been inimical to the long term market interests, stifling growth and promoting indiscipline.

The interdependence of insured insurer and reinsurer appears to have been forgotten and needs to revive. It needs to be appreciated that a situation that leads to demise of one will be fatal to the others as well. Already many reinsurers have perished, stopped or 
curtailed writing business. Hopefully the survivors can seize the opportunity to enforce on ceding companies terms and conditions that would make them take a more responsible attitude towards risk sharing. The fortunes of the two must run parallel. A situation where the ceding companies retained business is profitable whilst its reinsured business is regularly not or where and reinsurers participate only in the more hazardous or exposed business is not, in the long term, interest of anyone.

Leading reinsurers are rightly convinced of tie need to charge a premium for the risks they underwrite irrespective of the rates at which the ceding company may write the business. This is the only way they can ensure they have a pool sufficient to pay claims after leaving some margin for expense, profit and reserves. Measures have already been initiated in certain territories to control accumulations particularly in case of natural hazards, impose deductibles and insist upon minimum rates etc. and a tight reinsurance market has made this possible. This should be an ongoing process. The danger is that no sooner the markets improve there will be reinsurers particularly those who have not earlier suffered ready to undercut and acquire business.

Momentous changes appear inevitable over the coming years. They will present new challenges to Asian insurers and reinsurers who will have to contend with both structural changes in their markets and a inore demanding and competitive operative environment. They will need to put their houses in order now and prepare themselves for what looms head. Reinsurance itself is at the crossroads and insurers will find reinsurance support less readily available, more costly and subject to more onerous terms.

The challenges of the future can be met if all concerned Asian insurers and reinsurers and international reinsurers could collectively adopt a more responsible and realistic approach to create stable insurance markets in Asia based on sound insurance techniques without undermining them as in the past by unbridled competition. The present crisis should not be a cause for despair but an opportunity to transform the market so that all concerned would benefit and be able to continue their contribution to the industry. 